\title{
CRITICAL ANALYSIS OF REALIBILITY OF THE MODEL OF INVESTMENT CREDIT APPROVAL IN AGRICULTURE AND FOOD PROCESSING INDUSTRY ${ }^{1}$
}

\author{
Lidija Barjaktarović2, Renata Pindžo ${ }^{3}$, Azra Hanićc $^{4}$
}

\begin{abstract}
Summary
Investments are funds which are invested in certain manufacturing goods, revenue on investments, the process of investment, subject in which it is invested, and which is obtained as a result of the assessment of investment. Every rational investor entering into an investment expects some benefits. Entry decision into a particular investment project carries a business risk, both for investors and for the bank as co-financier of the project. Accordingly, the subject of this paper-research is a critical analysis of the reliability of the model of investment credit approval in agriculture and food processing industry (MICA) used by local banks when considering whether to financially support investment needs of large corporate customers in the segment of secondary agriculture production and food processing industry. Applying the model of the correlation analysis, the degree of interconnectedness of indicators of the quality of assets and business performances of Serbian banking sector are quantified.
\end{abstract}

Key words: investment, customer analysis, transaction analysis, cash flow, EBITDA.

JEL: Q14, P33, P34, P43

1 This Research Paper was the part of the project "Advancing Serbia's Competitiveness in the Process of EU Accession”, no. 47028, in the period 2011-2016, financed by Serbian Ministry of Science and Technological Development.

2 Lidija Barjaktarovic, Ph.D., Associate Professor, Singidunum University, Faculty of Business in Belgrade, Kumodraska Street no. 261a, Phone: +381 309 4094, E-mail: lbarjaktarovic@singidunum.ac.rs

3 Renata Pindzo, Ph.D., Associate Professor, Faculty of Economy, Finance and Administration and Ministry of Trade, Tourism and Telecommunications, Zorana Djindjica Boulevard no. 44, Phone: +381 26006 00, E-mail: renata.pindzo@mtt.gov.rs

4 Azra Hanic, Ph.D., Assistant Professor, Union University, Belgrade Banking Academy, Faculty for Banking, Insurance and Finance, Zmaj Jovina Street no. 12, Beograd, Phone: +381 2621 730, E-mail: azra.hanic@bba.edu.rs

EP 2016 (63) 3 (751-765) 


\section{Introduction}

Investments in the broadest sense are a necessary condition to achieve progress and the realization of continuous human efforts to master the forces of nature and efficiently use them for its own needs. (Jovanović, 2000) According to Bodie et al. (2008) an investment is the current commitment of money or other resources in the expectation of reaping future benefits. Furthermore, it is in accordance with Brealey et al. (2007) that today's investments bring benefits in the future. Moreover, Palepu et al. (2007) stressed that expected earnings and Return on Equity (ROE) are crucial for investments. Finally, it is in relation with Đuričin, Lončar (2012) that future (forecasted) profitability is important for investment decisions. The four basic elements of investment are (Barać et al., 2004): an entity that invests (investor), the object in which it is invested (the investment proposal or project), the price of renouncing of expenditure (interest rate) and the price of "Hope" (discount rate).

Sources of investment funding can be owned and borrowed (the company's balance sheet liabilities). The decision on the mean of financing depends on the return on investment (owned and borrowed). Also, the investments present a new incentive for company's overall business activities. The primary source of repayment is the income from the basic business operations of the company. However, many companies simply do not want to take the risk themselves and do not want to invest their equity without adequate credit support of the banks (Hanić, Pindžo, 2008).

The subject of this paper-research is a critical analysis of the reliability of the model of investment credit approval in agriculture and food processing industry (MICA) used by local banks when considering to financially support investment needs of large corporate customers. The aim of this paper is to show the possibilities of improving the reliability of MICA from the standpoint of reliability for decision-making in this domain. The basic hypothesis (H0) is: There is a reasonable doubt about the reliability of MICA used by commercial banks in the Republic of Serbia.

The basis for proving the hypothesis are official annual reports of Serbian banking which are available on the website of the National Bank of Serbia (NBS) and in the World Bank (WB), for a period of 2009-2014. Indicators of the subject of analysis are credits in use, asset quality expressed through the level of non-performing loans (NPL), amount of equity, capital adequacy ratio (CAR), ROE and Return on Assets (ROA). Onwards, Pearson correlation coefficient will be applied, in order to determine the effect of the applied MICA on the business banks performances, i.e. the impact of NPLs on the financial result and the capital of a bank.

Accordingly, the paper is organized in four parts. In the introductory part, subject, aim and hypothesis will be defined. Methodology will be described in the second chapter. In the third chapter literature review will be presented. In the fourth part research results will be presented. In the last chapter, concluding remarks will be presented. 


\section{Literature Review}

According to the data of the Business Registers Agency (APR), in the Republic of Serbia 120,614 business entities operate in 2015 (APR 2016). However, there is no publicly available information about their credit rating, made by independent external credit rating agencies.

In the following paragraphs, authors will present research results on the topic of quantitative factors in the client analysis - the objectivity of the financial statements, the instruments of financial analysis and opinion of an external auditor. In theoretical terms, Hopwood et. al., (2012), and, in our region, Belak (2011) are the authors who have worked extensively on the credibility of the financial statements as a basis for determining the creditworthiness of the client, i.e. on forensic accounting and auditing. The focus of their work was on the investigative actions about conducted fraud. In view of the fact that this is a current and interesting issue for the wider scientific and professional public, we have many studies, and articles on this subject, also, publicly published data of various relevant state institutions, which will be presented below.

According to CFE (2014), the third category of scams is false financial reporting (9\% of the total number, but causes the greatest financial effects, on average, a loss of USD 1 million). According to data of this association, fraudulent schemes in financial statements may relate to: (1) overvalue of assets and income (premature revenue recognition, notional incomes, hidden liabilities and costs, inadequate property valuation - overvalue, inadequate disclosure), or (2) underestimation of assets and income (disposal of revenue recognition, underestimated income, overvalue of liabilities and costs, inadequate valuation of property - underestimation).

Recent empirical studies on the subject of the credibility of financial statements carried out in our country (in the period from 2009 to 2015) provide a basis for the hypothesis that the degree of reliability and credibility of financial statements is relatively low. The reasons for this, as one may assume, are commonly found in the system of rewarding of managers and a desire to reduce the tax base, i.e., tax evasion (Mirdala et. al., 2014). Furthermore, research conducted among accountants (2014) showed that there was no clear boundary between creative use of accounting techniques and their misuse. Also, Mirković (2014) using Beneish M-scoring model, partly pointed to manipulation of financial results in the company Jedinstvo a.d. Sevojno in 2012 and 2013. Then Barjaktarović et. al., (2014) applying Benford's law on a sample of 847 large companies, which operated in the Republic of Serbia in 2012, indicated that there were grounds for doubt on stated financial results due to the regularity of the appearance of numbers 1 and 9. Moreover, Čerović et. al., (2015) on a sample of 4029 large and medium-sized enterprises operating in the Republic of Serbia, in the period from 2009 to 2013, applying the application of Benford's law, indicated that there were reasonable grounds to doubt on reported amounts of net cash flow from operating activities, due to the higher incidence of numbers 1 and 3, and lower occurrence of number 4 . The authors suggested that the reasons could be manipulative, but also ignorance of people that compose the cash flow statement. Next, Bugarčić (2015) pointed out to mistrust in the case of tax evasion and money laundering in the Republic of Serbia on the basis of cash payment transactions (owner's loan) and withdrawals from the 
account on the basis of forged business documents. Based on the survey conducted among accountants in Serbia in major cities (2015), had found that a small number of enterprises correctly: (1) calculate depreciation of fixed assets (assets amounted to $60.36 \%$ of all economic entities that have submitted data for statistical purposes for 2014) (Stanišić et. al., 2015), (2) use prescribed regulations for the assessment of depreciation claims and has no real analysis of conducted calculation in order to improve their performance in the coming reporting periods (Vićentijević et. al., 2015). Stanišić et. al., (2015) stated that there was a practice of buying (external) auditor's opinion.

According to the analysis Knežević et. al., (2013) many limits of the application of financial analysis existed, and the most significant were the following: identification of industrial categories of companies and intercompany relationships (group of connected companies), seasonal influences on the obtained values of indicators, published averages of industries were of an approximate character and in many cases represented a target of companies, the financial statements had been prepared using the historical cost basis without considering the impact of inflation, the relevant data on the balance sheet, etc. Furthermore, all the tools for determining the creditworthiness of the legal entity are mainly used by external users of financial statements, rather than by the employees of the company (Todorović et. al., 2013).

Bearing in mind that researches indicates that there are doubts about the quantitative elements which are used to determine the creditworthiness of the legal entity, the authors of this paper reflected on performance of banks in accordance with the assumed credit risks, given that so far no research was published that indicates suspicion of publicly disclosed information on the NBS website.

\section{Methodology}

The authors used data from primary researches conducted from 2005 to 2014 (during their active work in a bank as a consultant of banks and borrowers), secondary data published by NBS (in the period since 2009 until 2014), expert opinions (6 interviews with risk managers of local banks, representatives of supervisory departments of NBS / directly involved in banks' control/ and clients - borrowers in the Republic of Serbia in 2015), as well as information available on the internet sites of relevant institutions and analysed borrowers' enterprises. In addition to the descriptive statistical method, they also used the method of correlation analysis and approach model for researching about the problem of the reliability MICA used by domestic banks.

At the beginning, the authors will focus to the standard model used by commercial banks to approve investment credit in agriculture and food processing industry (MICA), and which is subject of critical analysis. After that, they will propose a quantitative model which will determine the connections between MICA and asset quality and profitability of Serbian banking sector. 


\section{Standard Model of Investment Credit Approval in Agriculture and Food Processing Industry by Commercial Banks in Serbia}

The research is based on existing procedures in Serbian banking sector. It includes official steps between departments and their responsibilities. Credit approval process consists of following steps: (1) credit request (prepared by the company), (2) credit application process (within the bank), (3) credit decision (yes or no), (4) credit contract conclusion (yes), (5) usage and (6) monitoring of the loan (yes). The first step is relevant for further research analysis. Banks' model for determining the creditworthiness of the customer includes (Barjaktarović, 2013):

(1) Clients' analysis - covers: soft (qualitative) and hard (quantitative) facts i.e. character and ability of client, which means the determination of net present value and cash flow from investment (primary source of repayment);

(2) Transaction analysis - covers: purpose and amount of the loan, impact of transaction on the balance sheet and income statement of the company, repayment possibilities, structure of the loan and security structure (collateral is the secondary source of repayment).

This model should provide bank with healthy credit portfolio i.e. customers which will be capable to repay the loan in time. Out of scope of the research is credit collection model within the bank.

The client's creditworthiness presents possibility to service his debts in the future, and includes: (1) the willingness (character) of customer, (2) the ability or solvency of client receivables (cash, capital, market capacity or collateral) to convert into money in the right time. Area of the qualitative analysis of the company includes: ownership structure, management of the company, the business strategy, analysis of the industry in which the company conducts business activity, an analysis of the market position of the company, the business cycle in which there is a company and SWOT analysis. Area of quantitative analysis of the company includes: analysis of the financial operations of the client in the broadest sense and all changes in its size and power. Sources of information for quantitative analysis of the client are: annual reports of the company (balance sheet, income statement, cash flow statement, annex), quarterly reports of the company, cost accounting, the projections of the company, the consolidated statements of the entity, the audit report of the legal entity, unqualified or qualified opinion of the third parties, and the reputation of auditors. The most important characteristic of agriculture and food processing industry comparing to other industries is seasonality of production and consequently, collection of receivables. Furthermore, the largest challenge in performing business is to find relevant heading instrument, in order to protect business from external factors which have influence on production and sales as well as on trends on financial market in terms of market risk protection. Finally, the relevant feature/attitude of credit beneficiaries in this industry is that they belong to the group of connected companies where the main shareholder is investment fund/s (main aim of existence is maximizing EBITDA, such as Danube Foods Group, etc.) or successful player in some other field of industry (main aim of existence is maximizing net profit, such as Victoria group or MK Group, etc.) which is not connected to the core business of the borrower. 
The cash flow statement gives information about the sources and using of cash (decrease). It is used to determine the funds available to the company that can be used in the process of repayment of overdue liabilities. Thereby, the creditor always determines cash flow projections more conservatively than the borrower (which includes the financial projections), in order to assess the worst-case scenario of the client's business and furthermore, the ability for servicing the debt on the basis of the approved loan in those circumstances. Furthermore, next essential element of quantitative analysis is ratio numbers that summarize the key relationships and results from the basic financial statements and indicate the financial performance of the enterprise.

Any rational investor entering into an investment expects concrete benefits and increase of present value of their investment. In order to make investment decision, investor and creditor, take in consideration the benefits and accepted risks (Barjaktarović, Ječmenica, 2011), i.e. make projections of income statement and cash flows. (Lončar et. al., 2015). In the conventional models of long-term financing, it is necessary in the first place to determine what are the additional (incremental) cash flows arising from the investment itself, i.e. which cannot resist without that and shall be calculated as:

\section{Cash flows from investment - Cash flows without investment.}

If the company already operates and wants to calculate net cash flows of the investment itself, the same can be done by creating a separate account in which the calculation of the primary sources of repayment are aside of the effects of the existing business. Projections of cash flows (forecasts) should show: what level of cash will be necessary for the duration of the investment, when will this need occur and how long there must be a certain level of cash. The result of the projection of cash flows is net cash flow after debt servicing. Net cash flow after debt service represents the total inflows and total outflows of funds from the business, investment and financial activity. Projections of cash flows (inflows and outflows) are derived from the previously projected income statement and balance sheet for each year of the projection.

\section{Evaluation Methodology /Analysis of the Standard Model of Investment Credit Approval in Agriculture and Food Processing Industry}

For the purposes of critical evaluation of the approval of investment credit in agriculture and food processing industry by commercial banks in the Republic of Serbia, the official indicators of the performance of the banking sector in the Republic of Serbia will be analysed, which are available on the websites of NBS and WB, from the period of 2009-2014. The subject of analysis are the following indicators: credits in use, asset quality expressed through the level of NPL, amount of equity, CAR, financial result, ROA and ROE.

Limitations of the analysis are as following: (1) the same NPL presents the corporate and retail sector in total; considering the individual values of disbursed credit, the percentage of participation of disbursed credit in corporate sector is higher than in retail sector; (2) demarcation of long-term and short-term credit approved to corporate sector is not possible; 
(3) data presented does not have information on the total number of banks, and which part refers to banks that lost the licence; and whether there have been selling transactions of NPL to another bank or investment fund or other interested party. (4) All data which are available on the website of the NBS are stated in dinars, regardless of the fact that the structure of placement of NPL is dominated by those with foreign currency clause - there is a question about rate applied (usually on the last day of the month / quarter analysis, without taking into account the fluctuations that were in the course of the year/period). In the case of WB, all results are presented in the foreign currency. (5) All banks in Serbia do not use the same methodology for expressing exposure to the credit risk and reserves in the level of capital; (6) customer segmentation of the legal entity is different from the defined strategy of each commercial bank that operates in the Republic of Serbia.

Onwards, Pearson correlation coefficient will be applied, in order to determine the impact of NPLs on the financial result and capital of the banking sector in the Republic of Serbia.

\section{Research Results}

The results of the applied MICA can be seen through the achieved results of the banking sector in the Republic of Serbia, such as the amount of credit in use, the amount of NPLs, the amount of capital, the CAR, the realized financial result, ROA and ROE. It should be borne in mind that the period from 2004 to 2008 was marked by expansive credit activity of commercial banks (which could be characterized as liberal policy of placing funds and, consequently, increasing NPL), and from the end of 2008 is the period when the first effects of the global economic crisis in our country were starting to be felt, which were experienced by all participants of the financial market, through commercial banks' increased aversion to risk. In the period from 2009-2012 the growth of credit activity largely continued, and in 2012 we had a slowdown in credit activities of banks. The picture is not clear due to the fact that: (1) A good number of domestic banks is in foreign ownership, and that the legal entities have the possibility to use cross-border credits from their headquarters or funds from abroad, where Serbia has an arrangement on the avoidance of withholding tax, and where the country risk is consequently $0 \%$. So, the price of credit (interest rate) was lower. In fact, these credits are registered to the NBS with a maturity of 13 months so they are credits in the long term and not short-term credits (liabilities). According to the recommended measures of the central banks of parent countries, from 2016 these credits should also be "transferred" to the domestic banks in the Republic of Serbia. (2) There are subsidized credit lines for the revival of corporate activity (since the widespread illiquidity of the economy began in 2009), where the state was late with the payment of subsidies and increasing the level of provisions of commercial banks in the coming years. (3) A number of state-owned banks have collapsed, some banks were taken over by foreign banking groups or investment funds, some banks continued to operate as a result of pioneering (where one bank bought the brand and assets were purchased by another bank) and there was a purchase of bad debts. However, we do not have transparent information about these types of activities. (4) There was a change of regulations in the way of expressing provisions on the basis of credit, of the classification of the client and taken collateral, i.e. of the structure of the credit transaction. Taking into 
account the described trends of the volume of credit, this indicator will not be relevant for further research about the reliability of MICA to the corporate entity.

On the other hand, in the same period, the level of NPLs is growing in absolute terms, as a result of: (1) Worsened creditworthiness situation of the borrower, due to difficulties in collection of receivables; (2) Exchange rate fluctuations, since the largest number of disbursed credits are with foreign-currency clause; (3) Fluctuations in the reference interest rate - EURIBOR, which is an integral part of the predominantly disbursed credit with variable interest rates; (4) Ways of managing in the commercial bank, i.e. established procedures in accordance with the legally defined risk management framework. Studies show that 5 of the 30 banks (at the end of 2015) show a transparent risk management process (research of authors on the basis of data available on the website of NBS). (5) Moral hazard, i.e., motivation of managers that realized targets in the bank in the short term when it concerns the amount of disbursed credit, and they will get a certain bonus, i.e. not an objective assessment of the assumed risk in relation to expected returns. (6) Worsened country risk - causal business practices whether or not the borrower needs to pay. Which instruments has monetary authority used to ensure stability of the banking system? (7) "Subjective" reporting of the healthy placement in stateowned banks that were the subject of sales (e.g. Novosadska bank had 60\% of NPL at the time of the sale to Erste group, and were portrayed to the potential investors as a healthy part of the credit portfolio). The largest number of activities of banks was aimed at resolving the existing NPLs, while a relatively little attention is paid to early recognition of potential NPL (i.e. Early Warning System - EWS). In the purpose of our further research, NPL will be taken as an important indicator of the reliability of approval investment credit to the entity.

The amount of capital has a fluctuating trend corresponding to developments in the market, in terms of: (1) Realized NPL and losses that are covered from the capital (in accordance with the Basel capital agreements guaranteeing the substance and determine what amount of maximum risk the banks are supposed to accept); (2) Reducing the number of banks that lost the licence. (3) As well as the capital increase that took place in order to maintain CAR at the appropriate level in the case of banks that remained open. CAR (according to the our legislation, account equity ratio and risk-weighted assets) is always above $19 \%$, which is significantly above the legal minimum of $12 \%$, which means that banks are overcapitalised and granting less loans to industry, i.e. that they have the money, but there is not enough good projects. The described trends of the volume of the capital are relevant indicator for determining the reliability of the investment credit approvals to the entity.

In the reporting period we can say that the banking sector had a positive financial result, especially in the first two years of the period under review (as a result of the growth of interest income based on extended credit). Then there was a drastic fall in 2011 (reduced level of disbursed credit, but the increased level of NPLs and provisions on the basis of assumed risks; also significant expenditure items are salaries, rental of office space and the cost of borrowed funds). The situation improved through the 2012 (a significant number of employees laid off, reduced the number of branches), in order to once again deteriorate in 2013 (primarily due to unpaid claims, and the cost of employees), and the improvement recorded in 2014 (reduced number of employees and drastically automated processes). If the indicators of profitability 
compared with other risk-free investment and investment in NBS repo-transactions can be concluded that the yield is less than non-risk investment (which realizes the historical minimum in the second half of 2015 and amounted to $4.5 \%$ p.a.), and that banks did not capitalize well the money for managing. It remains an open (non-transparent) issue of the impact of regulatory changes on provisions on the basis of the accepted risks arising from the credit transactions (consequently of foreign exchange, interest rate, operational and of liquidity risk). Bearing in mind the described movement of financial results, which also consist of interest income and expense, it will be subject to further analyse of the reliability model of the approval of investment credit in agriculture and food processing industry.

Table 1. Basic indicators of the performance of the banking sector in the Republic of Serbia in the period from 2009 to 2014 (in billion RSD / \%)

\begin{tabular}{|c|c|c|c|c|c|c|}
\hline Year/Indicator & 2009 & 2010 & 2011 & 2012 & 2013 & 2014 \\
\hline Credit & $1,278.3$ & $1,685.4$ & $1,671.5$ & $1,751.1$ & $1,686.1$ & $1,653.2$ \\
\hline NPL & 191 & 237.5 & 342.7 & 365.8 & 395.3 & 436.7 \\
\hline $\begin{array}{l}\text { NPL agriculture } \\
(\%)\end{array}$ & n.a. & 10 & 8 & 5 & 4 & 4 \\
\hline Capital & 368.6 & 407 & 322.4 & 350.1 & 347.1 & 316 \\
\hline CAR (\%) & 21.44 & 19.91 & 19.11 & 19.87 & 20.94 & 20.0 \\
\hline Financial result & 20,025 & 25,398 & 1,252 & 11,654 & $-2,100$ & 3,500 \\
\hline $\mathrm{ROE}(\%)$ & 4.6 & 5.4 & 0.24 & 2.05 & -0.36 & 0.58 \\
\hline ROA (\%) & 1.0 & 1.1 & 0.05 & 0.43 & -0.07 & 0.12 \\
\hline
\end{tabular}

Source: NBS (2009 - 2015), WB (2009-2015)

Next, the growth of NPL will be determined (because it is the only indicator which has a growth in the whole observed period; however, agriculture industry had increasing trend of NPL due to the fact that people during the crisis spent money on basic - life important items, but their percentage in total corporate credit portfolio of banks is low; furthermore NBS did not reported about NPL of food processing industry, which is relevant for people's survival in general, so there is no full relevant information for further analysis) and how it affected the financial result (due to the fact that this is an indicator that had the most drastic fluctuations in the period under analysis). For this purpose we use Pearson's correlation coefficient, where NPL is marked with an $\mathrm{x}$, while $\mathrm{y}$ designates the level of financial results at the sector level (results are shown in Table no. 2). 
Table 2. Pearson's correlation coefficient for the NPL and the financial result of the banking sector in the Republic of Serbia in the period from 2009 to 2014.

\begin{tabular}{|l|l|r|r|}
\hline \multicolumn{2}{|c|}{ Correlations } \\
\hline & & $\begin{array}{c}\text { Level of NPL-a (in } \\
\text { billion RSD) }\end{array}$ & $\begin{array}{c}\text { Financial results (in } \\
\text { billion RSD) }\end{array}$ \\
\hline \multirow{2}{*}{$\begin{array}{l}\text { Level of NPL-a } \\
\text { (billion RSD) }\end{array}$} & Pearson Correlation & 1 & -.881 \\
\cline { 2 - 5 } & Sig. (2-tailed) &. & .22 \\
\cline { 2 - 5 } $\begin{array}{l}\text { Financial results } \\
\text { (billion RSD) }\end{array}$ & Pearson Correlation & 6 & 6 \\
\hline & Sig. (2-tailed) & -.881 & 1 \\
\hline & $\mathrm{N}$ & .22 & 6 \\
\hline
\end{tabular}

Source: Authors' calculations, SPSS software

The resulting value of the Pearson correlation coefficient of -0.881 indicates a very strong relationship between the NPL and the achieved financial results. The result is logical given the fact that the credit is a basic banking product which generates a profit for the bank (principal, interest and related commission; or income arising from cross-selling products because with the conclusion of the credit agreement, the borrower may be directed to which other banking products he can use - payments, electronic banking, documentary products, etc.). If the results are considered in accordance with applicable regulations in the field of risk management and international accounting standards, we can say that the established connection makes sense, i.e. the amount of NPL, seen through the level of provisions for NPL, directly affects the financial results achieved in the context of that higher level of provisions includes a lower financial result, and vice versa. This further means that MICA is not set appropriately, in the sense that it the creditworthiness of the borrower, the amount and purpose of the placement, and the price of risk assumed is not adequately established. Further, it will be interesting to determine the effect of growth of NPL on the movement of capital in the banking sector in Serbia by using the Pearson correlation coefficient. Where NPL is marked with $\mathrm{x}$, and the y shows the capital of the banking sector in the Republic of Serbia (the results are shown in Table No. 3). 
Table 3. Pearson's correlation coefficient for the NPL and the capital/equity of the banking sector in the Republic of Serbia in the period from 2009 to 2014.

\begin{tabular}{|c|c|r|r|}
\hline \multirow{2}{*}{} & & $\begin{array}{c}\text { Level of NPL-a } \\
\text { (billion RSD) }\end{array}$ & $\begin{array}{c}\text { Capital/Equity (total) } \\
\text { (billion RSD) }\end{array}$ \\
\hline \multirow{2}{*}{$\begin{array}{c}\text { Level of NPL-a } \\
\text { (billion RSD) }\end{array}$} & Pearson Correlation & 1 & -.968 \\
\cline { 2 - 5 } & Sig. (2-tailed) &. & .002 \\
\cline { 2 - 4 } $\begin{array}{c}\text { Capital (total) } \\
\text { (billion RSD) }\end{array}$ & $\mathrm{N}$ & 6 & 6 \\
\hline & Pearson Correlation & -.968 & 1 \\
\hline & Sig. (2-tailed) & .002 & 6 \\
\hline
\end{tabular}

Source: Authors'calculations, SPSS software

The resulting value of the Pearson correlation coefficient of -0.968 indicates a very strong relationship between the NPL and capital. The obtained result is meaningful, because the height of the assumed credit risk, in the form of extended credit (and consequently during the validity period of the credit relationship it is possible that the borrower will be in trouble with credit repayment) is determined by amount of capital that a bank possesses. If the results which we obtained are interpreted in accordance with applicable regulations in the field of risk management and international accounting standards, we can say that established connection makes sense i.e. the amount of NPL, seen through the level of provisions for bad credit, directly affects to the amount of capital in the context of that higher level provisions for NPL includes the capital spending and vice versa. This further means that MICA is not set appropriately, in the sense that they do not perceive assumed credit risks in accordance with the amount of capital that the bank has, i.e. the creditworthiness of the borrower, the amount and purpose of the placement has not been adequately established, especially in terms of a group of connected companies, of the existing exposure at the time of placement of funds group of related parties.

Next, a potential agency problem, in the sense that manager's bonus is tied to the amount of disbursed credit but not for charging them. This means that placing a large amount to the client can easily achieve defined target and increases the level of credit risk. Since the long-term credit are usually granted to the legal entities with foreign currency and variable interest rates, increased the exposure of this type of risk, endangers the creditworthiness of the borrower, but also increases the level of provisions of commercial banks.

Doubts to the reliability of MICA in the part of determining the creditworthiness of the legal entity are already supported by the information of the research (conducted in the period from 2009 to 2015) regarding of the authenticity of the elements of quantitative analysis of the borrower (ACFE, Mirdala et. al., Mirković, Barjaktarović et. al., Čerović et. al., Bugarčić, Stanišić et. al., Stanišić et. al., Vićentijević et. al., Knežević et al., Todorović et. al.), in terms of: (1) presentation of items in the financial reports (assets, calculation of depreciation, devaluation of receivables, revenues, operating cash-flow, the realized financial 
result and applied financial analysis), i.e. practice of buying an external auditor's opinion. (2) The motives for the previously described actions (such as handling, tax, bonus payments, ignorance).

It can be concluded that the basic hypothesis are proven and that there is reasonable doubt about the reliability of MICA in commercial banks in the Republic of Serbia.

\section{Conclusion}

Research which is conducted in the period from 2009 to 2014 in the banking sector in the Republic of Serbia has shown that there is reasonable doubt about the reliability of MICA of commercial banks in the Republic of Serbia. The limitations that existed during the analysis do not diminish the significance of the results.

It was found using the Pearson correlation coefficient that NPL, as a result of set model for approval investment credit for agriculture and food processing industry, has a very strong link with the capital and the achieved financial results of the banking sector. It was the basis to further establish a causal link between the observed indicators, respecting the legislation in force in the field of risk management and of international standards of accounting reporting, based on the nature of the work which deals with the bank (credit placement). In the sense that it has not adequately established the creditworthiness of the borrower, the amount and purpose of the placement, and the price of risk assumed. This further means that the model of approval of investment credit for the agriculture and food processing industry to the large legal entities in use is not set appropriately, in the sense that they do not perceive assumed credit risks in accordance with the amount of capital that the bank has, or has not adequately established the creditworthiness of the borrower, especially in terms of the group of connected companies (investment fund or successful player in some other industrial sector), the existing exposure at the time of placement of funds of a group of connected entities. Also, there is a space for improvement of MICA in commercial banks in Serbia. Firstly and foremost, further education and training on the topic of financial literacy and business ethics of the employees of the bank, but also in the company of the borrower. In fact, everyone in the chain should look on that process as a lifelong learning process. Secondly, building partnerships between a bank and a client (the borrower), since only a healthy business cooperation of customer and the bank leads to making profit from their business. Thirdly, it should set an appropriate motivation system of employees (in the bank and to the business entity) which will be involved in evaluating and rewarding (as bonus would not be the only form of awards). Finally, negotiations with the various associations and relevant authorities in order to reduce tax burdens where possible, for the objective expression of the financial statements.

Future research will include reviewing of the applied model and the results achieved by any commercial bank in the Republic of Serbia, separately, in the segment of credit risk management of total corporate credit portfolio and specific - industry oriented corporate credit portfolio i.e. agriculture and food processing industry. 


\section{Literature}

1. ACFE (2014): Report to the Nations on Occupational Fraud and Abuse. [Retrieved from http://www.acfe.com/rttn/docs/2014-report-to-nations.pdf./ date of access on $\underline{12 / 20 / 2015]}$

2. Agencija za privredne registre (2016): Brojač. [Retrieved from http://www.apr.gov.

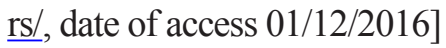

3. Barać, S., Ivaniš, M., Jeremić, Lj. (2004): Upravljanje finansijama (ISBN 86-8427722-8), Fakultet za finansijski menadžment i osiguranje, Beograd, Srbija

4. Barjaktarović, L., Milojević, M., Terzić, I. (2014): Results of Applience of Benford 's Law on Serbian Companies, The book of proceedings - XIV International Symposium, Symorg, June 2014 Zlatibor, The Faculty of Organizational Sciences, Belgrade, Serbia, pp. 696-702.

5. Barjaktarović, L. (2013): Upravljanje rizikom, (ISBN 978-86-7912-527-9), Univerzitet Singidunum, Beograd, Srbija

6. Barjaktarović, L., Ječmenica, D. (2011): Osvrt na implementaciju standard Bazela II u poslovanju bankarskog sektora Srbije, Menadžment, Fakultet organizacionih nauka u Beogradu, No. 59/2011, pp. 71-77, Beograd, Srbija,

7. Belak, V. (2011): Poslovna forenzika i forenzičko računovodstvo: Borba protiv prijevare, (ISBN 978-953-55423-2-2), Belak excellens, Zagreb, Hrvatska

8. Bodie,Z., Kane,A., Marcus,A. (2008): Investments (10 ${ }^{\text {th }}$ Edition, ISBN 0077861671), McGraw-Hill/Irwin Series in Finance, Insurance and Real Estate, New York, USA

9. Brealey, S., Mayers, S., Marcus, A. (2007): Principles of Corporate Finance (5th edition, ISBN 9780071105927). McGraw-Hill Company, New York, USA

10. Bugarčić, U. (2015): Fraud detection in companies, The book of proceedings FINIZ 2015, December 2015, Belgrade, University Singidunum, pp. 206-209.

11. Čerović, S., Barjaktarović, L., Milojević, M. (2015): Increased Country Risk Had Impact on Regulatory of Financial Reports of Companies-Serbian Case, The book of proceedings BASIQ 2015, June 2015, Bucharest, Romania, Editura ASE, pp. 267-275.

12. Djuričin, D., Lončar, D. (2012): Menadžment pomoću projekata, (ISBN 978-86-4031243-1), Ekonomski fakultet, Beograd, Srbija

13. Hanić, H., Pindžo, R. (2008): Some Financial Aspects of PPP Project Management, The book of proceedings of XII International Symposium on Project Management, YUPMA 2008, 14. - 15. May 2008, Zlatibor, YUPMA, pp. 65-70.

14. Hopwood, W., Leiner, J., Young, G. (2012): Forensic Accounting and Fraud Examination (2nd edition), (ISBN 978-0078136665), McGraw Hill Irwin, New York, USA

15. Jovanović, P. (2000): Upravljanje investicijama, (ISBN 978-86-86897-06-0), Grafoslob, Beograd, Srbija 
16. Knežević, S., Barjaktarović-Rakočević, S., Đurić, D. (2012): Primena i ograničenja racio analize finansijskih izveštaja u poslovnom odlučivanju. Menadžment, Fakultet organizacionih nauka u Beogradu, No. 61, pp. 25-32, Beograd, Srbija

17. Lončar, D., Barjaktarović, L., Pindžo, R. (2015): Analiza isplativosti investicionih projekata, (ISBN 978-86-84309-30-5), Ekonomski institut, Beograd, Srbija

18. Mirdala, R., Mizdraković, V., Arežina, N., Stefanović, D. (2014): Creative Accounting: from Creativity to Misuse, The book of proceedings FINIZ, December 2014, Belgrade, University Singidunum, pp. 5-7.

19. Mirković, V. (2014): Beneish M-scoring model: Case study of the company "Jedinstvo" a.d. Sevojno, The book of proceedings FINIZ 2014, December 2014, Belgrade, University Singidunum, pp. 135-137.

20. Narodna banka Srbije (2009 - 2015): Bankarski sektor: analize i izvestaji, Beograd, Srbija, [Retrieved from http://www.nbs.rs/internet/cirilica/55/55 4/index.html, date of access 01/12/2016]

21. Palepu, K., Healy, P., Bernard, V. (2007): Business Analysis \& Valuation Using Financial Statements ( $2^{\text {nd }}$ edition), Tomson South-Western, New York, USA

22. Stanišić, N, Radojević, T, Stanić, N., Rajin, D. (2015): The Association Between Auditors Switching and Audit Opinion in the Republic of Serbia, The book of proceedings FINIZ 2015, December 2015, Belgrade, University Singidunum, pp. 9-12.

23. Stanišić, M., Petrović, Z., Vićentijević, K. (2015): Research Irregularities in the Calculation of Depreciation of Fixed Assets in the Republic of Serbia, The book of proceedings FINIZ 2015, December 2015, Belgrade, University Singidunum, pp. 1-3.

24. Todorović, M., Mitrović, Z., Bjelica, D. (2013): Measuring Project Success in Project-Oriented Organizations, Menadžment, Fakultet organizacionih nauka u Beogradu, No. 68, pp. 41-48, Beograd, Srbija,

25. Vićentijević, K., Jović, Z, Petrović, Z. (2015): The impact of impairment of receivables on the reality of financial reporting in the Republic of Serbia, The book of proceedings FINIZ 2015, December 2015, Belgrade, University Singidunum, pp. 49-52.

26. World Bank (2015): Banknon-performing loans to total gross loans (\%), Washington, [Retrieved from http://data.worldbank.org/indicator/FB.AST.NPER.ZS/countries, date of access 01/12/2016] 


\title{
KRITIČKA ANALIZA POUZDANOSTI MODELA ODOBRENJA INVESTICIONOG KREDITA U POLJOPRIVREDI I PREHRAMBENOJ INDUSTRIJI
}

\author{
Lidija Barjaktarovič ${ }^{5}$, Renata Pindžo ${ }^{6}$, Azra Hanic $^{7}$
}

\begin{abstract}
Rezime
Investicije su novčana sredstva koja se ulažu u određena proizvodna dobra, prinos transformisanih novčanih sredstva, proces ulaganja, predmet $u$ koje se investira, $i$ koje se dobija kao rezultat procene investiranja. Svaki racionalan investitor ulaskom u neku investiciju očekuje konkretne koristi. Odluka o ulasku u određeni investicioni poduhvat nosi poslovni rizik, kako za investitora tako i za banku kofinansijera tog projekta. U skladu sa tim predmet rada je kritička analiza pouzdanosti modela odobrenja investicionog kredita za preduzeća u poljoprivrednoj i prehrambenoj industriji (MOIK) koji najčešće koriste domaće banke kada razmatraju da li će finansijski podržati ili ne investicionu potrebu velikog preduzeća u segmentu sekundarne poljoprivredne proizvodnje i prehrambene industrije. Primenom modela korealacione analize kvantifikovan je stepen medusobne povezanosti indikatora kvaliteta aktive i poslovnih performansi bankarskog sektora Srbije.
\end{abstract}

Ključne reči: investicija, analiza klijenata, analiza transakcije, novčani tokovi, EBITDA.

5 Vanredni profesor, dr Lidija Barjaktarovic, Univerzitet Singidunum, Poslovni fakultet, Ulica Kumodraška br. 261a, Beograd, Srbija Telefon: +381 30940 94, E-mail: lbarjaktarovic@singidunum.ac.rs

6 Vanredni professor, dr Renata Pindžo, Univerzitet Singidunum, Fakultet za ekonomiju, finansije i administraciju, Ministarstvo trgovine, turizma i telekomunikacija, Bulevar Zorana Djindjica br. 44, Beograd, Srbija, Telefon: +381 2600 600, E mail: renata.pindzo@mtt.gov.rs

7 Docent, dr Azra Hanić, Univerzitet Union, Beogradska bankarska Akademija, Fakultet za bankarstvo, osiguranje i finansije, Zmaj Jovina br. 12, Beograd, Srbija, Telefon: +381 2621 730, E-mail: azra.hanic@bba.edu.rs 